\title{
Aktivitas Enzim Endoglukanase (EG) dan Lignin Peroksidase dari Penicillium sp. Pada Media Pertumbuhan Bekatul dan Tongkol Jagung
}

\author{
Rahmasyitha, A.M., N.D. Kuswytasari, dan E. Zulaika \\ Departemen Biologi, Fakultas Ilmu Alam, Institut Teknologi Sepuluh Nopember (ITS) \\ e-mail: enny@bio.its.ac.id
}

\begin{abstract}
Abstrak - Bekatul dan tongkol jagung memiliki kandungan lignin dan selulosa yang tersusun oleh unsur nitrogen dan karbon. Sehingga bekatul dan tongkol jagung dapat digunakan sebagai media pertumbuhan fungi. Beberapa spesies jamur menghasilkan enzim endoglukanase (EG) dan lignin peroksidase (LiP). Penelitian ini bertujuan untuk mengetahui aktivitas enzim endoglucanase (EG) dan lignin peroksidase (LiP) pada Penicillium sp. dengan media pertumbuhan bekatul dan tongkol jagung. Aktivitas enzim endoglukanase (EG) diukur menggunakan metode DNS, sedangkan aktivitas enzim lignin peroksidase (LiP) diukur dengan metode oksidasi. Hasil penelitian menunjukkan bahwa aktivitas enzim endoglukanase (EG) dan LiP pada Penicillium sp. yang tertinggi pada media bekatul adalah sebesar 0,135 U/ml dan 32,131 U/ml. Pada media tongkol jagung aktivitas enzim endoglukanase (EG) dan LiP tertinggi adalah sebesar $0,104 \mathrm{U} / \mathrm{ml}$ dan $26,695 \mathrm{U} / \mathrm{ml}$.
\end{abstract}

Kata Kunci-Bekatul, lignoselulosa, Pennicillium sp., tongkol jagung.

\section{PENDAHULUAN}

L IMBAH Pertanian merupakan sumber daya alam terbarukan yang melimpah. Limbah pertanian mengandung biomassa tanaman yang paling mendasar yaitu lignin dan selulosa. Beberapa proses telah dikembangkan untuk memanfaatkan limbah pertanian sebagai bahan baku untuk produksi bahan kimia dan nilai tambah produk seperti ethanol, enzim, dan protein sel tunggal. Aplikasi limbah pertanian dapat memberikan alternatif substrat dan pemecahan masalah pencemaran lingkungan dari pembuangan limbah [1].

Lignin dan selulosa merupakan komponen utama pada tanaman yang mampu didegradasi secara enzimatik dengan enzim selulase, dan ligninase oleh mikroorganisme [2]. Mikroorganisme produsen enzim selulase dan ligninase diantaranya adalah kapang [3]. Penicillium sp. merupakan kelompok fungi berfilamen yang mampu menghasilkan enzim selulase dan ligninase, sehingga mampu mendegradasi lignin dan selulosa [4][5]. Kemampuan Penicillium sp. dalam mendegradasi lignin dan selulosa dapat menjadi agen hayati dan media pertumbuhan mikroorganisme composting fungi. Penelitian ini bertujuan untuk mengetahui aktivitas enzim endoglukanase (EG) dan lignin peroksidase ( $\mathrm{LiP}$ ) dari Penicillium sp. pada media pertumbuham bekatul dan tongkol jagung pada waktu inkubasi 15 sampai dengan 21 hari.

\section{METODE PENELITIAN}

Penelitian ini dilakukan pada bulan Mei hingga Juni 2018 di Laboratorium Mikrobiologi dan Bioteknologi, Jurusan Biologi, Fakultas Ilmu Alam, Institut Teknologi Sepuluh Nopember Surabaya.

\section{A. Alat dan Bahan}

Alat yang digunakan pada penelitian ini adalah Laminar Air Flow (LAF), autoklaf, oven, neraca analitik, vortex, magnetic stirrer, sentrifuge, spektrofotometer, erlenmeyer, jarum ose, cawan petri, tabung reaksi, botol selai $100 \mathrm{ml}$, cawan silinder, bunsen, beker glass.

Bahan yang digunakan dalam penelitian ini adalah limbah pertanian bekatul dan tongkol jagung, medium kultur Penicillium sp. yang didapatkan dari kultur murni Laboratorium Mikrobiologi dan Bioteknologi. Media kultur Potato Dextrose Agar (PDA), dan medium basal yang terdiri dari ekstrak yeast $2 \mathrm{~g} ; \mathrm{KH}_{2} \mathrm{PO}_{4}, 1,5 \mathrm{~g}$; $\mathrm{MgSO} 4.7 \mathrm{H} 2 \mathrm{O} 1 \mathrm{~g}$; $\mathrm{CaCl}_{2} .2 \mathrm{H}_{2} \mathrm{O} 0.2 \mathrm{~g} ; \mathrm{FeSO}_{4} .7 \mathrm{H}_{2} \mathrm{O} 0,2 \mathrm{~g} ; \mathrm{MnSO}_{4} . \mathrm{H} 2 \mathrm{O} 0,2 \mathrm{~g}$.

\section{B. Cara kerja}

1) Sub-kultur Penicillium sp.

Isolat Penicillium sp. masing-masing 1 ose diinokulasikan secara aseptis pada media Potato Dextrose Agar (PDA) miring. Diinkubasi pada suhu ruang selama 7 hari dan diamati pertumbuhannya.

2) Pre-treatment Substrat Bekatul dan Tongkol Jagung

Bekatul dan tongkol jagung diberi pretreatment secara kimiawi dengan penambahan $\mathrm{NaOH} 2 \%$ dalam Erlenmeyer dengan perbandingan 1:10, dipanaskan pada waterbath dengan suhu $85^{\circ} \mathrm{C}$ selama 6 jam [6]. Lalu padatan disaring. Padatan bekatul dan tongkol jagung yang telah terpisah dibilas dengan air hingga $\mathrm{pH}$ larutan menjadi 7. Padatan bekatul dipanaskan dengan oven sampai kering pada suhu $65^{\circ} \mathrm{C}$ selama 3 hari, lalu didinginkan pada suhu kamar [6]. 


\section{3) Produksi Kapang Pada Medium Bekatul dan Tongkol Jagung}

Suspensi spora sebanyak $10^{6}$ sebanyak $2 \mathrm{ml}$ dinokulasikan ke dalam substrat bekatul dan tongkol jagung. Pengulangan dilakukan sebanyak 3x dengan waktu inkubasi selama 14 hari, dan dilakukan pengujian dimulai pada hari ke-15 sampai 21 untuk uji aktivitas enzim endoglukanase (EG) dan lignin peroksidase (LiP).

3) Uji Aktivitas Enzim

Aktivitas enzim endoglukanase (EG) diukur menggunakan metode DNS [11]. Ekstrak enzim kasar diambil sebanyak $1 \mathrm{ml}$, ditambahkan $1 \mathrm{ml}$ substrat CMC $1 \%, 1 \mathrm{ml} 0,05 \mathrm{M}$ sodium buffer sitrat $(\mathrm{pH} 4,8)$ dan $1 \mathrm{ml}$ DNS kemudian dipanaskan pada air mendidih selama 5 menit sampai terjadi perubahan. Campuran kemudian didinginkan dan diukur absorbansi dengan spektrofotometer pada panjang gelombang $540 \mathrm{~nm}$. Nilai absorbansi dimasukkan pada persamaan kurva standard glukosa. Dalam penelitian ini perhitungan aktivitas enzim endoglukanase (EG) dinyatakan dengan $\mathrm{U} / \mathrm{ml}$. Perhitungan aktivitas enzim dilakukan pada hari ke-15 sampai 21.

Aktivitas enzim LiP dianalisis berdasarkan reaksi oksidasi veratril alkohol menjadi veratril aldehid [7] pada panjang gelombang $310 \mathrm{~nm}$. Komposisi bahan untuk uji aktivitas diperlukan komposisi bahan-bahan $0,1 \mathrm{ml} 8 \mathrm{mM}$ veratril

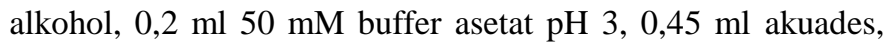
$0,05 \mathrm{ml} 5 \mathrm{mM} \mathrm{H}_{2} \mathrm{O}_{2}$, dan $0,2 \mathrm{ml}$ ektrak enzim kasar. Semua bahan tersebut selanjutnya dimasukkan kedalam kuvet dengan ukuran $2 \mathrm{ml}$, lalu dikocok secara perlahan. Kemudan diukur absorbansinya dengan spektrofotometer. Perhitungan aktivitas enzim dilakukan pada hari ke-15 sampai 21.

\section{HASIL PENELITIAN}

\section{A. Aktivitas Enzim Endoglukanase (EG)}

Uji aktivitas enzim endoglukanase (EG) menggunakan kurva standar glukosa untuk menghitung konsentrasi gula pereduksi yang ada pada larutan sampel. Dengan menggunakan kurva standar glukosa, maka didapatkan konsentrasi gula pereduksi yang digunakan untuk menghitung aktivitas enzim endoglukanase. Persamaan kurva standar yang diperoleh yakni y $=0,131 \mathrm{x}-0,131$ dimana y merupakan nilai absorbansi dan $\mathrm{x}$ adalah konsentrasi gula pereduksi hasil hidrolisis enzim. Glukosa yang dihasilkan oleh Penicillium sp. memiliki gugus aldehid yang akan mengalami oksidasi dan 3,5- Dinitrosalicylik acid (DNS) akan mengalami reduksi menjadi 3-amino-5nitrosalicylik acid yang memiliki warna kemerahan [7]. Warna kemerahan inilah yang akan ditangkap oleh spektrofotometer UV-VIS pada panjang gelombang 540 nm.

Nilai aktivitas enzim endoglukanase (EG) meningkat selama pengamatan. Secara umum nilai aktivitas enzim endoglukanase (EG) pada media bekatul dan tongkol jagung yang dihasilkan cenderung meningkat namun tidak signifikan seiring lamanya inkubasi (Gambar 1). Berdasarkan Gambar 1 aktivitas enzim endoglukanase tertinggi adalah aktivitas Penicillium sp. yang ditumbuhkan pada media bekatul yaitu $0,135 \mathrm{U} / \mathrm{ml}$. Aktivitas tertinggi terjadi pada hari ke-21 masa inkubasi.

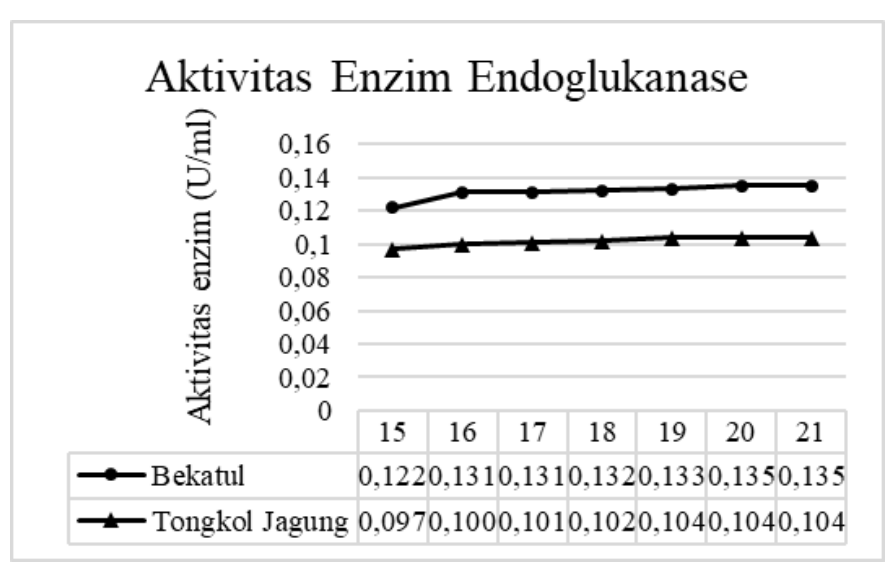

Gambar 1. Grafik aktivitas enzim endoglukanase (EG) pada media bekatul dan tongkol jagung

Sedangkan pada media tongkol jagung aktivitas endoglukanase tertinggi terjadi pada masa inkubasi hari ke-19 yakni sebesar 0,104 U/ml. Hal ini ini dikarenakan, bertambahnya waktu inkubasi maka aktivitas enzim semakin tinggi, hal ini disebabkan pada waktu tersebut pertumbuhan mikroorganisme telah mencapai maksimal, dan semakin lama waktu fermentasi maka aktivitas enzim cenderung meningkat karena waktu fermentasi merupakan waktu yang dibutuhkan enzim untuk memecah protein menjadi protein yang larut, dan dalam hal ini enzim merupakan protein yang sensitif terhadap lingkungan sehingga faktor substrat yang digunakan juga mempengaruhi nilai aktivitas enzim [8].

Pada penelitian ini aktivitas enzim endoglukanase Penicillium sp. pada media bekatul lebih tinggi yaitu sebesar $0,135 \mathrm{U} / \mathrm{ml}$ diikuti dengan tongkol jagung sebesar $0,104 \mathrm{U} / \mathrm{ml}$ (Gambar 1) dikarenakan kandungan selulosa pada media bekatul lebih tinggi 32,4\% daripada tongkol jagung sehingga pemecahan selulosa pada bekatul oleh enzim endoglukanase (EG) yang dihasilkan Penicillium sp. lebih tinggi. Hal ini dikarenakan substrat mempengaruhi aktivitas enzim, kandungan selulosa pada substrat yang lebih tinggi menjadikan aktivitas enzim selulase yang dihasilkan tinggi [4] dikarenakan terjadi pemecahan selulosa yang dimiliki substrat oleh enzim selulase, ditunjukkan dengan penelitiannya menggunakan Penicillium sp. yang ditumbuhkan pada media bagase tebu, jerami padi, dan tongkol jagung, yang menghasilkan aktivitas enzim selulase tertinggi pada media tongkol jagung yang memiliki kandung selulosa tertinggi sebesar 0,595 U/ml.

\section{B. Aktivitas Enzim Lignin Peroksidase}

Uji aktivitas lignin peroksidase di dasarkan pada kemampuan lignin peroksidase (LiP) dalam mengoksidasi veratril alkohol menjadi veratril aldehid dengan adanya $\mathrm{H}_{2} \mathrm{O}_{2}$ (Delila, 2016). Veratril aldehid yang terbentuk yang akan ditangkap oleh spektrofotometer UV-VIS pada panjang gelombang $310 \mathrm{~nm}$. Nilai aktivitas enzim lignin peroksidase (LiP) meningkat selama pengamatan. Secara umum nilai 
aktivitas enzim lignin peroksidase (LiP) pada media bekatul dan tongkol jagung yang dihasilkan cenderung meningkat seiring lamanya inkubasi (Gambar 2).

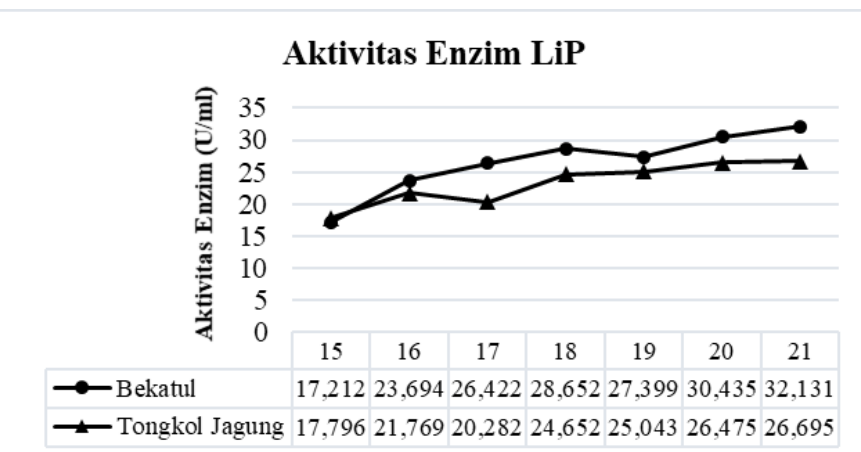

Gambar 2. Aktivitas enzim lignin peroksidase (LiP) pada media bekatul dan tongkol jagung

Berdasarkan Gambar 2 aktivitas enzim lignin peroksidase (LiP) tertinggi adalah aktivitas Penicillium sp. yang dikemas pada media bekatul yaitu 32,131 U/ml. Aktivitas tertinggi terjadi pada hari ke-21 masa inkubasi. Sedangkan pada media tongkol jagung aktivitas endoglukanase tertinggi terjadi pada masa inkubasi hari ke-21 yakni sebesar 26,695 U/ml. Hal ini sesuai dengan penelitian yang menyatakan bahwa waktu inkubasi terbaik media tongkol jagung yaitu maksimal 4 minggu dengan hasil aktivitas enzim LiP sebesar 555,56 U/ml [9]. Sedangkan pada nilai aktivitas media tongkol jagung hari ke-17 mengalami penurunan yaitu sebesar 20,282 U/ml, hal ini disebabkan saat masa panen untuk uji aktivitas bagian media yang diambil hanya mengandung sedikit isolat dikarenakan tidak meratanya saat pencampuran media dengan inokulum, sehingga ekstrak enzim yang dihasilkan sedikit dan nilai aktivitas menurun. Hal ini berkaitan dengan penelitian yang dilakukan yang menunjukkan bahwa kadar protein yang dihasilkan menurun dikarenakan faktor substrat yang digunakan tidak mengalami pengayakan atau pemerataan dengan baik sehingga mikroorganisme sulit untuk melakukan hidrolisis [8]. Pada penelitian ini aktivitas enzim LiP Penicillium sp. pada media bekatul lebih tinggi yaitu sebesar $32,131 \mathrm{U} / \mathrm{ml}$ diikuti dengan tongkol jagung sebesar 26,695 $\mathrm{U} / \mathrm{ml}$, hal ini berkaitan dengan penelitian yang menunjukkan bahwa Penicillium sp. mampu menghasilkan aktivitas enzim ligninase tertinggi yaitu sebesar $1140 \mathrm{U} / \mathrm{ml}$ pada media bekatul [11].

\section{KESIMPULAN}

Berdasarkan hasil penilitian, dapat disimpulkan bahwa aktivitas enzim endoglukanase (EG) dan LiP tertinggi pada media bekatul adalah sebesar $0,135 \mathrm{U} / \mathrm{ml}$ dan $32,131 \mathrm{U} / \mathrm{ml}$ sedangkan pada media tongkol jagung aktivitas enzim endoglukanase (EG) sebesar $0,104 \mathrm{U} / \mathrm{ml}$ dan aktivitas enzim LiP 26,695 U/ml.

\section{DAFTAR PUSTAKA}

[1] E. . Oliveira, L.A., A.L.F. Porto, "Production of Xylanase and Protease by Pennicillium Janthinellium CRC 87M-115 from Different Agricultural Wastes," Biosources Technol., vol. 97, pp. 862-867, 2006.

[2] R. Pandey, A.; Soccol, C. R.; Nigam, P.; Soccol, V. T.; Vandenberghe, L. P. S.; Mohan, "Biotechnological potential of agro-industrial residues. II: cassava bagasse," Bioresour. Technol, vol. 74, no. 1, pp. 81-87, 2000.

[3] dan E. H. Samsuri M., B. Prasetya, "Biodegradasi Bagasse oleh Jamur Pelapuk Puth (White Rot Fungi) dan Potensi Pemanfaatannya untuk Etanol," in Prosiding Nasional Indonesia XIII, 2004, pp. 405-410.

[4] N. . Alfiah, I., dan Kuswytasari, "Produksi Enzim Selulase Oleh Pennicilium sp. Pada Suhu, pH, dan Limbah Pertanian yang Berbeda," J. SAINS POMITS, 2012.

[5] N. . Mustofa, D.H, dan Kuswytasari, "Studi Aktivitas Enzim Selulase dari Varian Isolat Kapang Wonorejo Surabaya dalam Media Eceng Gondok (Eichhornia crassipes)," J. SAINS POMITS, 2012.

[6] Y. S. Rilek, N.M, N.Hidaya., "Hidrolisis Lignoselulolitik Hasil PreTreatment Pelepah Sawit (Elaeis guineensis Jacq) menggunakan H2SO4 pada Produksi Bioetanol," J. Teknol. dan Manaj. Argoindustri, vol. 6, no. 2, pp. 76-82, 2017.

[7] F. dan A. L. N. A. Isrami, "Aktivitas Selulase dan Xilanase dari Komplek Enzim Lignoselulolitik Termostabil Hasil Penguraian Batang Pisang," J. Kim. Sains, vol. 17, no. 2, pp. 17-22, 2014.

[8] M. W. A. Sulisyarsi, A., Pujiati, "Pengaruh Kosentrasi dan Lama Inkubasi terhadap Kadar Protein Crude Enzim Selulase dari Kapang Aspergilus niger," in Proceding Biology Education Conference, 2016, pp. 781-786.

[9] D. dan Liling, "Isolasi dan Seleksi Kapang Strain Lokal Penghasil Lignin Peroksidase dari Kulit Kakao Lapuk Perkebunan Kakao Sepawon Kabupaten Kediri," Universitas Muhammadiyah, 2016. 